Fr. Janusz Królikowski*

UPJPII, Kraków-Tarnów

\title{
CULTURE, EDUCATION AND TRUTH. THE PERSPECTIVES ON HELP OFFERED TO CONTEMPORARY YOUTH
}

This paper focuses on three fundamental notions-realities which describe human life and constitute at the same time its foundation and the space of participation in it. The triad culture - education - truth describes the most essential human experiences, simultaneously, defining the direction of their deepening and creative developing. Certainly, in the times like these when everything is questioned notions-experiences that belong to this triad are not problem-free. What is more, they are deemed to be superfluous, especially in ultra-left-wing ideologies in which suicidal tendencies are easily discernible. Taking this into consideration, it is hardly possible to avoid polemic attitude towards numerous questions even those most essential since in their semantic field the greatest confusion may be detected. That is why there are numerous attempts to answer the question how, in the face of such a dynamic spiritual condition of the world, those fundamental issues can be dealt with within the frames of anthropology, and how they can be justified from the anthropological point of view. This reflection is rather philosophical in character, however, it is also inspired by the fundamental Christian truth which says about the incarnation of the Son of God and about the salvation of man made by Him.

The situation of young people in today's world is extremely complicated since as never before - they are constantly put under numerous ideological pressures and exposed to diverse political influences. The problem is that it all happens too early. Before they acquire the ability of independent and critical reasoning and stand a chance to take autonomous decisions which may become the affirmation

* Fr. Janusz Królikowski - priest of the diocese of Tarnów, the dogmatic theologian, professor at The Pontifical University of John Paul II in Krakow, Faculty of Theology Section in Tarnow; e-mail: janusz.krolikowski@upjp2.edu.pl; ORCID: 0000-0003-3929-6008. 
of themselves, they are subjected to various manipulations and lead astray. Consequently, only with difficulty do they manage to find the way of freedom suitable for human dignity ${ }^{1}$. We do not despair, nor do we become the prophets of doom when we witness such a situation and warn against it. Our crucial and fundamental question is, how to help the contemporary youth without imposing anything and without resorting to pressures (which will not bring any positive results), so that they could find a way to realise their dignity and its proper attributes. It seems that this is the most fundamental question which we can and which we should ask ourselves in regards to the situation of the so called "contemporary youth". It is all about becoming patient and creative companions in a journey on which young people set out today, as their peers did in all other epochs before, taking into consideration the personal realisation of oneself and the participation in history of the communities to which they belong and which are the appropriate environment for their life and development. Therefore, it simply deals with the basic question concentrating on the search for what is essential in human life and in human destination².

To answer somehow the question posed in this paper, I refer to the reflection over the three fundamental notions-realities which describe human life, constitute its foundation and the space of the participation in it. The triad of culture - education - truth describes the most essential human experiences defining at the same time the direction of their deepening and creative developing. Certainly, in the times like these, when virtually everything is questioned, the notions-experiences which belong to this triad are not problem-free, what is more, they are deemed to be superfluous, especially in ultra-left-wing ideologies in which suicidal tendencies are easy to trace. Taking this into consideration, it is impossible to avoid a polemic attitude towards numerous issues, even those most fundamental, since in their semantic field the greatest confusion can be detected.

\section{METHODOLOGICAL NOTE}

I put forward and develop the problem formulated in the title philosophically according to the classical method of philosophizing even though it may appear

This article is an elaborated and extended version of the paper Culture, education and truth, in: Wychowanie w prawdzie o człowieku [Education in Truth about Man], ed. M. Kaczor, D. Świadkiewicz, Zielona Góra 2008, pp. 10-21.

2 The burning issue of education has been discussed many times by Pope Benedict XVI. Cf. P. Dal Toso, Papa Benedetto XVI e il compito urgente dell'educazione, Città del Vaticano 2011; M. Crocciata, Comunità ecclesiale e società civile di fronte alla sfida dell'educazione, in: La sapienza del cuore. Omaggio a Enzo Bianchi, joint publication, Torino 2013, pp. 299-315. 
incomprehensible and fail to meet with instant recognition. The gradual recapture of the territory by this model of philosophizing, especially in anthropological matters, encourages to go back to this particular way of philosophizing. It can be described as the "strong" method because it is directly connected with metaphysics but it is also the way which allows for the optimistic perspective on a human and his spiritual abilities ${ }^{3}$. One of the substantial advantages of this kind of philosophizing is that it recognises culture as the proper expression of man a person, and indicates to its "edifying" and successfully influencing role in human formation and in finding inspiration for his choices.

The notion of culture is ambiguous and very complex - this complexity becomes even more valuable when a culture is juxtaposed with a civilization. A culture, regardless of how we will define it, exerts a specific influence on education, in other words, on how we shape a human throughout his entire life. The whole idea encompasses as well the notion of truth which influence upon human, his choices and endeavours is exceptionally significant. A human is a being made of truth and for truth; thus, the quality of man's truth speaks about him. The idea of truth is especially important from the Christian point of view for the fact that it is directly linked to the evangelical understanding and proclamation of freedom, that is, the expression of human existence which defines man not only in terms of his spirituality but also determines the directions of commitment for his benefit in every aspect of both earthly and strictly spiritual life. It should not be forgotten that the proclamation of universal freedom is strictly Christian in its origin and associates with the fundamental statement of Saint Paul from his Epistle to the Galatians: "It is for freedom that Christ has set us free" (5:1) which marks the new stage of freedom in human history; the ultimate stage which becomes the foundation of the Christian proclamation as the "law of freedom" (James 2:12).

The extensiveness of this matter is the reason why the reflections presented in this paper will be far from perfection and mostly arguable and by the same token also insufficient. Nevertheless, I cherish the hope that they will become an introduction to the broader discussion which in the present state of affairs seems to constitute a priority. It appears that the principle of negation of the triad included in the title has reached the critical point beyond which there is no way to go. Therefore, the only option is the way back which - although very timidly - manifests itself as the only suitable solution ${ }^{4}$. Shall we pluck up the courage and take this road openly and act accordingly, or shall we look down on it as if it was only

Cf. E. Agazzi, Paidéia, verità, educazione, Roma 1999.

4 The important perspectives on this matter, based upon personal experiences of the author, formerly avowed Marxist, were presented in: A. MacIntyre, After Virtue. A Study in Moral Theory, University of Notre Dame Press 1981. 
a manifestation of "reactionary ideologies" which should be definitely rejected, alongside with everything that is classical, even if there is no sufficient argumentation for it? ${ }^{5}$ But is it alright to swim with the current of history and narrow everything down to pragmatism?

\section{CULTURE AS PAIDEIA - EDUCATION AND TRADITION}

In its original meaning the term culture applied to human is synonymous with the term education which puts in the first place the will "to take up with love" what may "shape" man or let him achieve "education" or, in other words, "refinement" - being refined in feeling, understanding and pursuing, namely being capable of making decisions, therefore being a free human. Culture is both freedom and an education for freedom although it does not possess means to make a particular human ultimately free. To accept oneself with love means to "give oneself" entirely; those who do so in reference to what is favourable to them become ready to "dwell inside", to live in one's self, and to go on a collision course with the surrounding reality. It is a kind of relation which makes possible a transition from the one who is educated to what educates him (devotion to values), that is, to what makes him "objective", and the entering of what educates him into himself, so that he accepts it as his own, and performs his "impersonalisation". This double transition does not make any changes, nor does it mix two separate elements but on the contrary it synthesizes them in a service of man.

This transition is fulfilled by means of "collision" which takes place inside a person. Education is not a passive acceptance of the ideas from the outside but a personal, independent and creative reproduction of them, and that is why it educates taking care of the process of assimilation, so that it would be a personal act because only then will it have a formative character; on the one hand, it is like staying in the opposition but with readiness and love at the same time. This kind of attitude, being the token of thinking and increase of freedom, clearly differentiates man from other creatures which are insistently trained and mechanically conditioned for something, so that they could repeat whatever is embedded in their brains. The man who shapes himself this way can be called colendus which means worthy of respect and he is so because cultivating himself he respects those values which have "educated" him. Such a human lives by those values and, however demanding they are, they define a demanding way of living. Anyway, it could

For similar ideas cf. eg. J. Habermas, Die Nachmetaphysische Denken, Frankfurt a. M. 1988; K.-O. Apel, Die Nachmetaphysische Philosophie, Köln 1991. 
be asked whether any other way of living is possible. At this point we could refer to the words of Saint Paul who simply describes the Christian fullness of life as "labour prompted by love" (1 Thessalonians 1:3).

This is how culture becomes - as I have mentioned before - synonymous with education, that is, paideia in the full sense of the word. On the one hand, it includes integrally functioning and involvement of all human powers (each and every human being in its integrity), so that they would bear good "fruit", and on the other hand, it includes works of art which affect the man and which are able to shape him and make him free through education. I am talking about precious works dealing with values and covering a wide range of topics, which constitute products of a given culture but they were discovered and enriched by a human who produced them independently, that is, ethically ${ }^{6}$. Since they belong to precious works which were "handed down", they are protected from oblivion although they are not secure from lapse of time. Moreover, time "takes care" only about valuable things which are worthy of being handed down from generation to generation. In fact these are the elements of tradition and as such they are formative in character or they constitute subjects of studies. They are living and relevant since the tradition which is constantly reintroduced is always contemporary and never becomes an archaeological museum. What is more, they produce another works of art and generate wealth and welfare which are only supplementary in character because they provide means which turn out to be appropriate and favourable for education and culture (environment, implements etc.).

It is difficult to think of any alternative approaches concerning education although actually there are some. Nevertheless, education understood in the way which is discussed here, has been elevated to the authentic concept of culture; we are all summoned to promote it, which concurrently provides the best way of educating or cultivating ourselves, instead of depreciating or disturbing or even suppressing it. Education understood in this way, as it was mentioned before, is accompanied by a substantial number of attitudes which are called virtuous ${ }^{7}$. Simply speaking, it is all about self-education which cannot be obtained if it is not already inside a person even though everyone is entitled and obliged to engage all their abilities even if they are not very much impressive.

6 Cf. R. Ingarden, Ksiażeczka o człowieku [Little Book on Man], Kraków 1987, pp. 21-25; J. Tischner, Myślenie wedlug wartości [Thinking in Values], Kraków 1981, pp. 363-373.

7 The significance of virtue in education is also discussed in: J. Woroniecki, Wychowanie człowieka. Pisma wybrane [The Education of Man], Kraków 1961; J. Królikowski, Zrehabilitować cnotę. Poszukiwania teologicznomoralne [The Rehabilitation of Virtue. Theological and Moral Searches], Tarnów 2004, pp. 45-57. 
Therefore, culture understood as paideia involves two different kinds of creativity. First of all, it is the ability of self-education which is invariably a personal act of creativity, even if it is supported by school in the most common sense of the word or by other institutions, which pursue educational objectives. On the other hand, it is the ability to create a new culture or, in other words, to introduce tradition into modernity without which man loses his ability of shaping or forming and educating himself. Only constantly renewed culture can cherish living and lasting tradition which can be revived and nurtured, so that it could be handed down to next generations of learners and teachers who would consequently take care of its further evolution and development. The ability of learning and educating and the ability of cultivating and creating of a new culture are evidently necessary whenever education or formation is concerned to which everyone is entitled, even those who have no opportunities to create works of art which would contribute to the development of education of everyone (even those, who understand little or nothing). This education or formation constitute a universal measurement of freedom of every human being.

If, on the other hand, a culture is narrowed down only to artefacts, whatever they are (whether they are more or less civilised or refined) of this or that stage of human development, way of living, feeling, judging etc., or the way of their propagation, then the whole concept of culture is altered and becomes a description of the social life of the community. It is also an aspect or a stage of culture but not the very concept of it. The life of the community is a culture only in a broad sense and only when brought to a level on which all nations and humans in all epochs would be always "educated", namely "colendi", which of course is definitely an oversimplification. The concept of culture deprived of its intensity and depth, in this way leads to the negation of human development and negation of any other cultural development. It stretches horizontally until it becomes synonymous with a culture of idols and platitudes which is based on manipulation that gathers and describes the greatest possible number of criteria to reduce them at the end to a common denominator. Coincidentally, it encompasses preposterous endeavour to combine opposites, which today is regarded as a manifestation of exceptional spiritual nobility. At this point there is a threat that culture will be substituted by anti-culture in the full sense of the word, namely by methodical negation of everything.

\section{THE GREEK PAIDEIA}

Greeks, and most of all Plato and Aristotle, were the first to develop the authentic concept of culture as education although with some shortcomings and 
limitations ${ }^{8}$. After that the concept was taken up in Roman humanitas which was developed theoretically especially by Cicero and Varro. Paideia means research in which man studies himself ("know thyself") to learn who he is and how he should lead his life so that he could fully and maturely realise himself as a human. That is why, in terms of human formation, culture is synonymous with searching for truth in all fields which may fall within the range of man's interest and contribute to his internal development and find their expression in his undertakings. For the same reason paideia poses the problem of what knowledge actually is or what is the level of reflection which analyses not only this or that subject but also the reflection over the very principle of knowledge, that is, the first truth which constitutes the foundation of all knowledge and for which human is an intelligent being, capable of understanding the surrounding reality. This fundamental principle can be associated with the first logos, that is, being. Philosophy is the knowledge which analyses being as its subject. When it investigates human being, any other being and a real being in general, then we are talking about ontology, and when it studies the principle of knowledge or, in other words, the principle of the first truth identified with being, then it is called metaphysics?

That is why philosophising in the very methodical sense of the word takes the first place in human formation. Culture cannot be reduced only to the understanding of more and more ideas but above all it is the knowledge about who the man is and what the meaning and sense of his existence is. This is the reason why we want to know more and more about man himself, so that it could be possible to show a certain way of realisation of his goal. The problems discussed by philosophy are not and cannot be treated as negligible, even if today there is a tendency to eliminate them because they affect not only human as an intelligent entity but also other forms of his reflection, even those initial or different from philosophy.

Rejection of philosophical problems is equivalent to depriving culture understood as paideia of its meaning since man shapes himself to such an extent in which he knows himself and realises himself in his unity. Therefore the supremacy of philosophising understood as especially formative "practising" of thinking ability (habitus) is in a sort indispensable for every man who is more intellectus than ratio, so that he could be different from other living creatures ${ }^{10}$. Its goal is to

\footnotetext{
Works of Werner Jäger remain irreplaceable in study of paideia in Greek tradition, especially Paideia: The ideals of Greek Culture, trans. by G. Highet, Oxford University Press 1939-1944.

9 For the importance of the idea for education conf. L.J. Elders, Éducation et instruction selon saint Thomas d'Aquin. Aspects philosophiques et théologiques, Paris 2012.

10 A question could be asked if depriving man of his originality and unity with the whole living world (not only the animal one) is not one of the sever results of the resignation of philosophical thinking and therefore, it may have grave legal and ethical consequences.
} 
make bonds with the first truth, that is, a being, so that he could take part in this truth/being. Therefore, philosophising is found at the beginning of every educational process and simultaneously constitutes its highest level, which is present in every person as a human. Philosophical inquiry is constitutive for a man and does not reduce culture to the very facts, familiar phenomena or various ways of living; thus, philosophy becomes a form incarnated in every human. This kind of philosophy, or in other words the concept of knowledge or science reserved for "philosophers", has been developing since the times of ancient thinkers like Heraclitus and Parmenides, creatively exerting consolidating effect on succeeding human generations. Numerous attempts to disprove logos or the truth as the subject of the most primeval research and the source of genuine culture and "humane" education, the advent of which dates back to Protagoras, lead to destruction which devastates man and humanity.

In every epoch, as Plato said, there are a lot of Sophists but few philosophers ${ }^{11}$. Protagoras and Plato, in different measure, are present in every man and they struggle with each other at every time and place. On the one hand, the love of "shaping oneself" to be culti is present in every one of us, even if we were served a poison in exchange. On the other hand, there is also a strong feeling of compromise, which diminishes the truth to promote wilfulness even if it is evident that we will fall victim to the destruction which the wilfulness brings along.

\section{THE CHRISTIAN PAIDEIA}

Christianity has inherited and adopted the concept of culture understood as searching as its own. This searching is aimed at man himself, so that he could learn, as far as it is possible, the truth about his being, as well as about the meaning and sense of his existence. This cognition is not complete and sufficient to answer these fundamental questions, but it remains valuable, and to certain extent it can be recognised as a very basic spiritual experience. This searching is not separated from the research concerning the world in which the man lives. That is why man has created various fields of cognition and numerous scientific disciplines. For this reason, he proposes a new approach to philosophy, that is, to the reflection over the principle of knowledge, or as a matter of fact, over the first truth about being. He does not regard science as a goal of culture and of man; he does not find it indispensable for the formation of a free man; and does not confine the concept

11 All those tendencies which were somehow inspired by Jacques Derrida and which advocate deconstruction as the appropriate way of philosophizing in our times, should be find as the major, and deceptive symptom of sophism in contemporary philosophy. 
of culture as paideia to so called high culture namely literature, art, science and philosophy. Culture, that is, education encompasses also moral and religious culture, shaping life fulfilled in prayer, in meditative concentration, in works of spiritual and sensual love which later becomes also spiritual if it undergoes the process of internal purification and elevation on religious ground. In this way the classical concept of culture defined by esprit de géométrie and designed for sheer intellectual contemplation enriches humanity so that it would become more understanding and profound in terms of esprit de finesse which does not call for rejection or negation of intellect, but transforms it into the intellect of love which means that in love it achieves its fulfilment and highest development. Simply speaking, a Christian in contradiction to an ancient Greek does not find knowledge to be the aim of culture, education, freedom and salvation of man and the reason which makes him different although he does not contrast the two epochs in human history, that is, before and after Christ. A Christian confides in God and His grace and he believes in Jesus Christ the Liberator and Saviour. A Greek trusts entirely in man and his abilities to achieve liberation and salvation although, as Plato remarked, scientific cognition in oneself, which is the joy of rational soul, can be obtained in "another world", but it always realizes through the natural actions of man.

Therefore, the primacy which Greek paideia situates in philosophy and human logos, Christianity, on the other hand, places in religion, namely, in the connection between man and God or more precisely with incarnated Word of God or Truth which appears as a person. Religion becomes the relation which totalizes all other human relations ${ }^{12}$. "I am the Truth" - says Jesus Christ (John 14:6). That is why Christian faith does not depend on books, but it depends on one Book - The Bible, that is the text which was revealed and speaks about works and words of God for man's benefit. It is not teachers, but the internal Teacher, Jesus Christ who is always present and who speaks in every man of goodwill; Jesus Christ - the miraculous light of the truth ${ }^{13}$. Jesus Christ cannot be reduced to philosophy even the most spiritual, to this or that or the whole knowledge, because Jesus encompasses inexhaustibly all human activity even the most humble one, on condition that it involves cognition and intelligence in some extent. What becomes fulfilled in Christian spirit is always elevated to the meaning of "mission" or testimony given to God and Christ here on earth, with concurrent employment of a means-talent which can be "used appropriately" only through conscience and moral deeds, that is, freedom. From the Christian point of view the minimum of talent equals to the maximum measure of the achieved goals of human fulfilment if it is employed with all good-

12 Cf. B. de Margerie, Mélanges anthropologiques à la lumière de saint Thomas d'Aquin, Paris 1990, pp. 51-64.

13 Cf. L. Freeman, Jesus: The Teacher Within, 2000. 
will and in order to form or "educate" oneself or, in other words, to refine oneself to answer better in purity of mind and will to the Word revealed, to content of faith and to its commandment concerning the love of God with "all thy heart, with all thy soul, with all thy strength" and "thy neighbour as thyself". Thanks to all that a better understanding through the owned light of the mind is achieved. As Richard of Saint Victor concluded accurately: "Love is the sight, and to love means to see"14.

That is why the Book does not eliminate or depreciate other books but delivers us from the conceit of books and all other great works of "intellect" in general, should they be accidentally recognized as the only knowledge worthy of this name and coincidentally foolishly diminishing other forms of formative cognition ${ }^{15}$. The teacher within does not eliminate or depreciate other teachers but he embarrasses them and tells them to place themselves in a correct perspective in relation to the only Teacher, namely, to Jesus Christ. He does not eliminate or depreciate science but the man's conviction about himself being autonomously and independently the principle-creator of truth (or its destroyer) and that he can learn all about everything, fulfil himself and save through the knowledge only, whereas his ultimate goal is Wisdom; the only saving Word of God ${ }^{16}$. He does not reject knowledge but the haughtiness of so called intellectualists who fool and depreciate goodness "which is invisible" together with silent love and humble work, without eyes shut on these significant and constitutive elements of culture understood as formative education ${ }^{17}$. For this reason, from the Christian point of view every human activity can be regarded as culture, that is, paideia if only the man thinks and does what he really thinks, and acts to realize integrally his being and his abilities, and does so in order to know even better who he is and - contemplating himself - testifies with profound conviction about his faith. This is what defines the consistent release of the internal freedom or, in other words, the transition from the freedom of nature to the freedom of a person as Saint Maxim the Confessor would say ${ }^{18}$.

14 Richard of Saint Victor, De gradibus charitatis, PL 196, 1203: „Amor oculus est, et amare videre est".

15 For further reading on the application of ancient pedagogical experiences, i.e., the figuratively mentioned "books", by the first Christians cf. J. Królikowski, Prymat wychowania w trosce o człowieka i jego bezpieczeństwo. Doświadczenie chrześcijańskie [The Primacy of Education in Care about Man and his safety. Christian Experiences], in: Bezpieczeństwo w warunkach zmian spolecznych, cywilizacyjnych $i$ kulturowych [Safety and the Changes in Society, Culture and Civilisation], ed. S. Bębas, P. Kowalski, Piotrków Trybunalski 2014, pp. 229-253.

16 Cf. E. Gilson, Mądrość i czas [Wisdom and Time], in: Człowiek w kulturze [Man in Culture], vol. 6-7, Lublin 1995, pp. 403-416.

17 Cf. J. Daniélou, La cultura tradita dagli intellettuali, Torino 2012.

18 Cf. B. De Angelis, Natura, persona, libertà. L'antropologia di Massimo il Confessore, Roma 2002, pp. $180-200$. 
The traditional concept of "liberal arts" (artes liberals), which are the only ones which are worthy of a free man, develop here a new meaning because the Christian concept of freedom is completely new. To be free does not mean to be born as a "free" man in the Greek sense (not a slave), and to cultivate the arts which are appropriate for this particular social status (status) because everyone is free wherever he is born and whatever he does. Complete and inviolable freedom is given to him ontologically; whatever obstacle on its way equals to the diminishing of human being, violation, abuse and injustice ${ }^{19}$. Ontologically this situation gives every man the obligation and the right to education for being free - to shape his freedom, so that it could achieve its fulfilment in truth. Such education consists in refraining from wrongdoing and from evil in general but also in eager "practicing" of doing all possible good at any time and place if only he is able to do so since the true foes of his freedom are not the obstacles which can be found outside (by the way, instigated by the people who undertake actions that are evil) but those which are caused by freedom itself. The evil deeds that man commits gradually ensnare and enslave him. Therefore, the first education for freedom equals to the practicing of feeling, thinking and craving for good which means the "culture" that is not irrelevant to the moral rules for the price of plunging into the anti-culture because the moral rule is the same as the rule of the truth, the light of being, the rule of knowledge as such. For Christianity, not only knowledge but also morality are not the salvation of man even if they are necessary so that he could pursue his proper goal. What is more, the very scientia inflat and the ethical virtues are only splendida vitia if they lack in Wisdom, that is, the Word of God which is inseparably Logos and Caritas.

The Christian concept of culture as the reality shaping the free man turns out to be constituted by two fundamental factors:

1. the first truth of being, that is logos providing the foundation, the ontological element of thinking and the rule of objectivity, without which thinking and knowing would be impossible;

2. the Word revealed, which turns to the light of thought as such, namely, to a man as an "intelligent" being, in order to raise him to God.

The first factor which makes a man an intelligent being assumes in its extension and infinite possibilities that a man can experience the ability of doing, namely, that he can refer to various forms of cognition (various sciences, whatever they are, also the new ones which are yet to appear) and manifold ways of acting; thus, it assumes practical activity in the broadest sense of the word. All these share educational character and value; hence, they contribute to the creation of culture, its

19 Cf. R. Spaemann, Kroki poza siebie. Przemówienia i eseje I [Steps beyond Ourselves], trans. J. Merecki, Warszawa 2012, pp. 243-259. 
stages and forms. The second factor, with respect to the autonomy of the first one, means that God creates man free and different from Himself; He endows him with the status of a finite being and with autonomy. The Christian God is not a "tyrant" - he is a Father, he is a monarch, but it could be said that a "constitutional" one. $\mathrm{He}$ makes that man, whatever stage of his culture is or of the truth which he seeks and discovers, raises himself to the Wisdom, to the ultimate perfection or fulfilment of every man and the whole mankind. He makes that man grows according to the dialectics of tradition and progress which constitute two inseparable concepts, because the loss of the former results in the loss of the latter ${ }^{20}$.

This Christian ideal of culture is in certain degree aristocratic in character although in a quite different sense than the classical one. It is aristocratic because every way of life and activity which contributes to the formation of a free man, that is, a better man can be called a culture and education (the culture which is not only basic, middle or high in reference to the "sense" of beauty and sanctity, love and poverty as for example in Saint Francis of Assisi, but also very low one). This culture is not aristocratic in the sense that it is limited for those only who were born free (aristocratic birth) yet incapable of it; it does not refer also to those who would be able and worthy to realise it (aristocracy of talent); and finally it is not for those who possess means to purchase it (financial aristocracy). The new aristocratic ideal of culture is maximally extensive with minimal loss of distinction: everyone can become "better" because everyone, proportionally to their abilities and with the help of others, can strive for perfection - in their integrity, that is, in union of body and soul - which means that they can educate themselves and become free. A slave regardless of a numerous obstacles can realize paideia, that is, culture better through moral, religious and philosophical nobleness than his master who could contribute more to the creation of culture by his deeds. The authentic paideia is measured with the level of the achieved internal freedom which expression is ethos and the highest fulfilment is heroism ${ }^{21}$. In terms of sublimity this Christian conviction has no equal among other pedagogical traditions.

All that has been said here, does not diminish culture by making it designed for ignorant people, apart from the fact that an ignorant person can be better educated than an "indoctrinated fool". Even the humblest action, if it is aimed to improve man, is always educational, that is, cultural and by the same token sublime;

20 About the meaning of tradition which is nowadays broadly contested check J. Pieper, Tradition als Herausforderung, München 1963.

21 It has to be reminded that the especially significant concept of heroism was presented by rev. Konstanty Michalski in his work Między heroizmem a bestialstwem [Between Heroism and Bestiality], Kraków 1949. Although it was not finished it includes valuable ideas which deserve development and further argumentation. 
as for example, a simplest prayer of an illiterate if strengthen by faith can make him wiser and freer than Aristotle. Not everyone is capable of producing new cultural values but it does not entitles them to depreciate and neglect culture. Moreover, those who are more advanced are obliged to educate the "lower" who can always become educated and "better", and if they are fully engaged they achieve the level of those more advanced and become "shaped" as well. Those who waste their talents are less educated and their charges are graver than those who developed their single talent completely and properly and by actualizing their abilities made perfection real. Therefore, it can also be said that a greater contribution to culture is made by a person who can educate themselves on different levels, becoming a creator of the new culture the fruit of which enrich the common good which is culture itself as the entity of valuable products or formative devices.

Christianity has always condemned intellectual conceit and vanity which the highest manifestation is gnosis. There is plenty of it and it is continually reborn in a mysterious way but it has no justification. Thus, as can be rightfully stated, Christianity has not "extended" the concept of culture but it has deepened it, simultaneously, making it more universal, that is, humane. It can be identified with education for freedom and that is how its aristocratic character is revealed. Christianity has promoted those who make themselves "better" to the rank of cultural aristocracy. It has appreciated those values, without depreciating or understating others, which are normally not taken into consideration by so called cultural people because of their foolishness which they are proud of. Those values are only revealed to sensitive and subtle people who can perceive them even in minor and concealed things.

The Christian ideal of culture is contemplative as well. Also in this respect it is realised in a different way than it happened in the case of the Greek ideal. What man thinks and does consciously, from the humblest work to the most sublime speculation, assumes certain degree of observation and reflection; it requires "slowing down, in order to see" and to "evaluate". "Stop to see" - means that Christian contemplation does not consist in giving up acting to find shelter in sheer scire, but rather in "standing in being", that is, in the principle of truth, in order to see the very acting from the inside, which means: to act contemplating and to contemplate acting. These two moments in their dialectic synthesis encompass the whole Christian paideia and constitute the Christian concept of culture: neither to be without to act, nor to act without to be. Therefore, to contemplate means to "see creatively", whereas doing is a "contemplative acting". It requires, as it has been noticed before, total engagement in the world - encompassing culture and knowledge in a double meaning of individual and communal formation, and the creation of works as a common good. It is not a sufficient condition but 
a necessary one since culture is a preparation or education for the beatific vision of God, the ultimate goal and the earned salvation, that is, engaged to the benefit of God and His Word which among Its requirements for the absolute readiness in Its favour (the first commandment) calls for the absolute readiness in favour of the world (the second commandment); It does not demand two separate acts of love but only one: love of God and love of thy neighbour at the same time. This is the completeness of the Christian paideia which is the completeness of culture, of freedom of an individual and of the whole humankind. The "word" and the actions of a person are in "harmony" with the words and actions of everyone, like his spirit is "accordant" with all spirits. This is the integral paideia of the integral man, son of God, reborn in Christ, Word and Truth which made him free.

\section{BIBLIOGRAPHY}

Agazzi E., Paidéia, verità, educazione, Roma 1999.

Angelis B. De, Natura, persona, libertà. L'antropologia di Massimo il Confessore, Roma 2002.

Apel K.-O., Die Nachmetaphysische Philosophie, Köln 1991.

Dal Toso P., Papa Benedetto XVI e il compito urgente dell'educazione, Città del Vaticano 2011.

Daniélou J., La cultura tradita dagli intellettuali, Torino 2012.

Elders L.J., Éducation et instruction selon saint Thomas d'Aquin. Aspects philosophiques et théologiques, Paris 2012.

Freeman L., Jesus: The Teacher Within, 2000.

Gilson E., Mądrość i czas, in: Czlowiek w kulturze, vol. 6-7, Lublin 1995, pp. 403-416. Habermas J., Die Nachmetaphysische Denken, Frankfurt a. M. 1988.

Ingarden R., Ksiażeczka o człowieku, Kraków 1987.

Jäger W., Paideia: The ideals of Greek Culture, trans. by G. Highet, Oxford University Press 1939-1944.

Królikowski J., Zrehabilitować cnotę. Poszukiwania teologicznomoralne, Tarnów 2004.

Królikowski J., Prymat wychowania $w$ trosce o czlowieka i jego bezpieczeństwo.

Doświadczenie chrześcijańskie, in: Bezpieczeństwo w warunkach zmian społecznych, cywilizacyjnych i kulturowych, ed. S. Bębas, P. Kowalski, Piotrków Trybunalski 2014, pp. 229-253.

MacIntyre A., After Virtue. A study in Moral Theory, University of Notre Dame Press 1981.

Margerie B. de, Mélanges anthropologiques à la lumière de saint Thomas d'Aquin, Paris 1990.

Michalski K., Między heroizmem a bestialstwem, Kraków 1949. 
Pieper J., Tradition als Herausforderung, München 1963.

Richard of Saint Victor, De gradibus charitatis, PL 196.

Spaemann R., Kroki poza siebie. Przemówienia i eseje I, trans. J. Merecki, Warszawa 2012.

Tischner J., Myślenie według wartości, Kraków 1981.

Woroniecki J., Wychowanie człowieka. Pisma wybrane, Kraków 1961.

Wychowanie w prawdzie o człowieku, ed. M. Kaczor, D. Świadkiewicz, Zielona Góra 2008.

Keywords: culture, education, paideia, truth, logos, incarnation

KULTURA, WYCHOWANIE I PRAWDA. PERSPEKTYWY POMOCY OFEROWANEJ DZISIEJSZEJ MŁODZIEŻY

\section{Streszczenie}

Artykuł niniejszy podejmuje refleksję nad trzema podstawowymi pojęciami, a tym samym kryjącymi się rzeczywistościami antropologicznymi, które opisują życie ludzkie oraz konstytuują jego fundament, na którym może się ono autentycznie rozwijać. Triada kultura - wychowanie - prawda opisuje podstawowe ludzkie doświadczenia formacyjne, a tym samym wskazuje najbardziej właściwy kierunek ich twórczego rozwoju w służbie człowieka. Trzeba na tę triadę zwrócić uwagę przede wszystkim z tego powodu, że we współczesnym wychowaniu i działalności formacyjnej uległa ona nie tylko osłabieniu, ale pod wpływem idei postmodernistycznych zostaje rozbita, a tym samym prowadzi do wyzwolenia nawet samobójczych tendencji u dzisiejszej młodzieży. W wielu przypadkach unika się mówienia o kulturze i prawdzie w kontekście wychowania młodych ludzi. Wprawdzie podjęta refleksja ma bardziej filozoficzny charakter, to jednak trzeba na jej problematykę zwrócić uwagę także w teologii, która przecież zwraca się do człowieka, na którego dzisiejsze ideologie mają bardzo znaczący wpływ. W świetle nauczania papieża Benedykta XVI także w teologii musimy zdać sobie sprawę, że ,pilne zadanie wychowania" młodego pokolenia jest ważnym zadaniem teologów, a więc powinno się odzwierciedlić także w uprawianej teologii.

Słowa kluczowe: kultura, wychowanie, paideia, słowo, wcielenie 